\title{
Understanding the responsiveness of local-level e-Governance platforms of Bangladesh
}

\author{
Saima Khan \\ Faculty, Department of Computer Science \& Engineering \\ University of Development Alternative \\ Bangladesh \\ saima.khan@cse.uoda.edu.bd
}

\author{
Moinul Zaber \\ United Nations University \\ Operating Unit on Policy-Driven Electronic Governance \\ (UNU-EGOV), Portugal \\ zaber@unu.edu
}

\begin{abstract}
Bangladesh is an emerging developing country. In recent years the country has shown remarkable progress in many key human development indicators. However, still many challenges remain as here $24.3 \%$ population lives in poverty [7]. The government's capability in ensuring better service delivery is one of the prerequisites of ensuring further development. The emergence of E-governance has opened up new possibilities for the governments in the global south. This paper is dedicated to assessing Bangladesh's progress in facilitating E-governance at the local level. For the last few years, the Bangladesh government has given its efforts to enhance online-based applications to make government services easier and faster. According to UNDP, Bangladesh that was in the 134th position in 2010 has only reached 119th in 2020 [15]. However, this indicator gives on an aggregate idea and does not let us understand the condition at the local level. In this paper, we assess the 12 City Corporation websites of Bangladesh. We have combined two different models (UN's five-stage model [10], [11] and Kriyar's 4 stage model [2]), for this assessment to cater to the context of the local government in the developing world context. A survey was performed from the 1st week of May 2020 to the last week of June 2020. The analysis shows that most city corporations meet emerging and enhanced presence but none ensures participative presence. Most corporations don't have any transactional presence. Overall, the assessment confirms the disparity among the local governments that is not understandable via national-level assessment. The findings of the results can be valuable for the policymakers contemplating on designing more effective e-government design at the local level in the developing world.
\end{abstract}

\section{CCS CONCEPTS}

- Applied computing $\rightarrow$ Computers in other domains $\rightarrow$ Computing in government $\rightarrow$ E-government

Permission to make digital or hard copies of all or part of this work for personal or classroom use is granted without fee provided that copies are not made or distributed for profit or commercial advantage and that copies bear this notice and the full citation on the first page. Copyrights for components of this work owned by others than ACM must be honored. Abstracting with credit is permitted. To copy otherwise, or republish, to post on servers or to redistribute to lists, requires prior specific permission and/or a fee. Request permissions from Permissions@acm.org.

ICEGOV'20, September 23-25, 2020, Athens, Greece

(C) 2020 Association for Computing Machinery.

ACM ISBN 978-1-4503-7674-7/20/09...\$15.00

https://doi.org/10.1145/3428502.3428556

\section{KEYWORDS}

E-government, E-govt. for Local governments, E-governance in developing countries, UN's 5 stage model.

\section{ACM Reference format:}

Saima Khan, Moinul Zaber. 2020. Understanding the responsiveness of local-level e-Governance platforms of Bangladesh. In Proceedings of the $13^{\text {th }}$ International Conference on Theory and Practice of Electronic Governance (ICEGOV2020), 23-25 September 2020, Athens, Greece, 4 pages. https://doi.org/10.1145/3428502.3428556

\section{INTRODUCTION}

Modern digital technologies are making people's way of living faster and easier. These services are getting fast appreciation in the governmental environments as well. Governments around the world provide various services like providing passports, licenses, and many other services to the people through the internet and other technologies. E-Government is now becoming a way of providing many government services through the use of digital innovations. An effective e-government system can make people's life better and it's capable of saving huge time [13], [14].

According to UNDP, Bangladesh over the last decades has seen tremendous economic growth [7]. But because of the constant threat of shocks-natural, economic, political, competitive trade impediment, the uncertain impact of globalization, etc., growth rates of Bangladesh can be impeded. However, challenges such as potentially losing preferential market access will increase in upcoming decades [7]. With 0.608 HDI scores, Bangladesh ranks 136th among 189 countries (according to the report of UNDP 2018) [7]. But according to the UNDP report of 2008, the rank of Bangladesh was 135th with the HDI score of 0.614 . A basic need to confront these challenges is good governance [14]. Government services need to be reached in every corner of this country. In this context, in a resource contained country like Bangladesh, effective 
e-governance can help reduce many of the obstacles. The governance challenges at the local level are different from the national levels. in this paper, we focus on the state of egovernance at the local government level.

We have started research in 2019 to provide the overall scenario of Bangladesh Govt. websites by assessing their services. There is a total of 12 City Corporations in Bangladesh. City Corporations are responsible for performing various administrative tasks. In this paper, we analyze all the available websites of City Corporations in Bangladesh.

Bangladesh is a densely populated country with a very small landmass [17]. The country is divided into 8 administrative divisions -Dhaka, Chattogram, Barisal, Sylhet, Rajshahi, Khulna, Mymensingh, and Rangpur. Dhaka division has 4 city corporations (Dhaka North City Corporation, Dhaka South City Corporation, Gazippur City Corporation, and Narayanganj City Corporation ), Chattogram division has 2 city corporations (Chattogram City Corporation and Cumilla City Corporation) and the rest 6 divisions have different single city corporation for each of them. A brief description of all the City Corporations of Bangladesh is present in [18]. All of the city corporations have their official websites except Barisal city corporation.

We have used a model in this research which has 5 stages. We have followed Kriyar's 4 stage model [2] and the UN's 5 stage model [10] [11] to design our proposed model. The outcome of this assessment can help the government to improve the web services by knowing in which area they should focus on upholding the target of benefiting people from better e-governance experience.

Research Objectives:

- Understand and evaluate the state-of-art of e-governance of Bangladesh trough evaluating the websites/portals of the Bangladesh government.

- In this research, all the available city corporation websites of Bangladesh have been chosen to evaluate the e-government status.

- Provide a mechanism for the local governments to assess their e-government maturity over time

\section{BACKGROUND}

\subsection{Brief Introduction with E-Government System for local governance:}

In short, E-govt means the use of communication technologies to provide govt. services to the citizens and other organizations to make the communications easier and faster. Zhiyuan et al., (2002) said that to understand e-government, people have to understand administrative development and reform on the government in general [3]. Zhiyuan et al., (2002) described eight types of egovernments and some main features of a good e-government system [3]. Some of the main features of good E-govt. are comprehensiveness, integration of data, iniquitousness, transparency, accessibility, strong security, strong privacy, reengineering, inter-operability, etc. [3].

\subsection{Various Types of E-Govt. Models}

Abdulmula et al., (2017) described 6 renown e-govt. models (UN's stage model (2001), Layne and Lee's Stage Model (2002), Moon's Stage Model (2002), Baum and DI Maio's Model (2000), Hiller and Belanger's Model (2001), Wescott's Model (2001)) [4]. We have also studied the research paper of Kriyar et al., (2011) [2], where they have assessed the E-government of Indonesian and Cambodian local government and central government websites using a 4-stage model. We have reviewed a total of 7 e-govt. models. All the models have the almost same type of concepts but they have operations at different levels.

An electronic government model (e-government model,2001) [10][11] has been suggested by the UN's (United Nations and American Society for Public Administration). This model consists of a total of 5 stages. The 5 stages of this model [4] are described below:

i Emerging Presence: This stage provides some limited formal basic information about the website and its services.

ii Enhanced Presence: specialized dynamic information is being provided in this stage.

iii Interactive Presence: This stage provides a way of interaction between the users and service providers.

iv Transactional Presence: Its task is to ensure complete and secure transactions such as renewing visas, providing passports, money transactions, etc.

v Fully Integrated Presence: Its goal is to provide a universal website where users will have comfortable and instant access to all kinds of services.

Kriyar et al., (2011) have followed a 4-stage model in their research in evaluating the e-government of Indonesian and Cambodian central and local government websites [2]. The 4 stages of this model are described below:

i Web Presence: This stage is a simple and basic presentation of a website.

ii Interaction: Interactions between citizens and government are possible in this stage.

iii Transaction: Citizens are enabled to perform various necessary transactions like filing taxes, updating personal information, etc. in this phase.

iv Participation: This stage is about to attend various online government activities.

\section{METHODOLOGY}

\subsection{Design of the Method}

Based on the UN's 5 stage model [5] and the 4-stage model of Kriyar et al., (2011) [2], we have designed a new 5-stage model for our research. We have chosen stage 1 to stage 4 from the UN's 5 stage model [4] and we have chosen the stage "participation" from Kriyars' 4 stage model [2], which is known as "Participative Presence" in our model. Using these total 5 stages, we have designed the new model for conducting the survey. We haven't used the stage 5 ("Fully Integrated Presence") of UN's 5 stage 
Understanding the responsiveness of local-level e-Governance platforms of Bangladesh

model in our model, because this stage is very advanced and not suitable for the context right now. we have taken the "participation" stage from Kriyar's model because we find it as a very important stage for the evaluation.

A total of 27 important parameters have been used to evaluate the websites of the city corporations in Bangladesh. Most of the parameters have been chosen from various published sources [1], $[8,9]$ where the same type of parameters have been used to assess a country's service condition and some parameters have been chosen from the parameters of the research paper of Kriyar et al. (2011), [2]. All the parameters have been described in section 3.4 of this paper. A total of 27 parameters were categorized into 5 stages of our designed model. Stage 1 contains 8 parameters, stage 2 contains 10 parameters, stage 3 contains 4 parameters, stage 4 contains 3 parameters and stage 5 contains 2 parameters. For each stage evaluation, we maintain a distinct document with the parameters on one side of the document and municipality website lists on another side of the document. Binary digits ( 1 or 0 ) are used to show the presence or absence of a specific parameter for each website. We have presented the total score of each website for each stage in percentage form. For example, if a particular website satisfies 4 parameters among a total of 8 parameters in a specific stage evaluation, we give that website a score of $50 \%$ for that specific stage.

We have started to conceive the analysis from July 2019. Part of that analysis has been presented in this paper. We have conducted the final survey for this research from the 1st week of May 2020 to the last week of June 2020. During this time, nothing on the websites have been changed. All the City Corporation websites are accessible from the 3 most used web browsers in Bangladesh. The most used web browsers in Bangladesh are Google Chrome, Mozilla Firefox, and Opera Browser.

\subsection{Description of Each Stage of Our Model}

In table 1 , We have mentioned the parameters of each stage in a tabular form.

Table 1: Categorization of the Parameters for Each Stage. Parameters for each stage have been enlisted in this Table

\begin{tabular}{|c|c|c|c|c|}
\hline $\begin{array}{l}\text { Stage-1 } \\
\text { Emerging } \\
\text { Presence }\end{array}$ & $\begin{array}{c}\text { Stage-2 } \\
\text { Enhanced } \\
\text { Presence }\end{array}$ & $\begin{array}{c}\text { Stage-3 } \\
\text { Interactive } \\
\text { Presence }\end{array}$ & $\begin{array}{c}\text { Stage-4 } \\
\text { Transactional } \\
\text { Presence }\end{array}$ & $\begin{array}{l}\text { Stage-5 } \\
\text { Participa } \\
\text { tive } \\
\text { Presence }\end{array}$ \\
\hline Accessibility & $\begin{array}{c}\text { Compatibilit } \\
\text { y with } \\
\text { Different } \\
\text { Web } \\
\text { Browsers }\end{array}$ & Forms & $\begin{array}{l}\text { Form Fill up and } \\
\text { submission }\end{array}$ & $\begin{array}{l}\text { Online } \\
\text { Survey }\end{array}$ \\
\hline $\begin{array}{l}\text { About Us } \\
\text { Feature }\end{array}$ & Sitemap & $\begin{array}{c}\text { Email } \\
\text { Interaction }\end{array}$ & $\begin{array}{c}\text { Transaction of } \\
\text { Payments }\end{array}$ & $\begin{array}{l}\text { Online } \\
\text { Voting }\end{array}$ \\
\hline $\begin{array}{l}\text { Contact Us } \\
\text { Feature }\end{array}$ & $\begin{array}{l}\text { Search } \\
\text { Feature }\end{array}$ & $\begin{array}{c}\text { Online } \\
\text { Discussion }\end{array}$ & $\begin{array}{l}\text { License and } \\
\text { Other Permits }\end{array}$ & \\
\hline Language & $\begin{array}{l}\text { Information } \\
\text { about } \\
\text { Services of }\end{array}$ & $\begin{array}{l}\text { Writing } \\
\text { Comments }\end{array}$ & & \\
\hline
\end{tabular}

ICEGOV 2020, 23-25 September 2020, Athens, Greece

\begin{tabular}{|c|c|l|l|l|}
\hline & $\begin{array}{c}\text { Municipaliti } \\
\text { es }\end{array}$ & & & \\
\hline $\begin{array}{c}\text { Evidence of } \\
\text { Updates }\end{array}$ & $\begin{array}{c}\text { Accessibility } \\
\text { through } \\
\text { mobile } \\
\text { devices }\end{array}$ & & & \\
\hline $\begin{array}{c}\text { General } \\
\text { Activities }\end{array}$ & $\begin{array}{c}\text { Regular } \\
\text { Update }\end{array}$ & & & \\
\hline $\begin{array}{c}\text { Fast } \\
\text { Loading } \\
\text { Time }\end{array}$ & $\begin{array}{c}\text { Layout and } \\
\text { Design }\end{array}$ & & & \\
\hline $\begin{array}{c}\text { Presence in } \\
\text { the First } \\
\text { Page of } \\
\text { Search } \\
\text { Engine }\end{array}$ & Content & & & \\
\hline & & & & \\
& Availability \\
of Links of \\
Important \\
Official & & & & \\
& Pages & & & \\
& Effective & & & \\
Navigation: & & & \\
\hline
\end{tabular}

\section{DATA}

A total of 12 city corporation websites of Bangladesh, were checked. Among the 12, we could assess only 11 as the official website of Barisal city corporation was not found for after searching. The dataset is given in [19]. All of these city corporations' websites have been evaluated in our research, based on some consistent parameters [8,9]. Different stage of this model has a different number of parameters. The websites have been reviewed each week from the first week of May 2020 to the last week of June 2020.

\section{RESULTS AND DISCUSSIONS}

The assessment outcome is shown in table 2. Among the 12 City Corporations in Bangladesh, Barisal City Corporation does not have its official website. Dhaka North city corporation and South city corporation show slightly better performance than other city corporations. Cumilla, Rajshahi, Chattogram, Khulna city corporations' websites are still at the rudimentary stage. Some of the City Corporation websites have various useful options (Option button) of services in the menu bar. Some option buttons work and provide useful information and other services. But some option buttons don't work. Some websites have the "contact us" feature on their web page. But when a user clicks this feature, no email address/phone number or other addresses are found.

\section{Table 2: Assessment of Websites of Bangladeshi Municipalities (\%)}

\section{(Survey of May 2020-June 2020)}

\begin{tabular}{|l|l|l|l|l|l|}
\hline & $\begin{array}{l}\text { Stage- 1 } \\
\text { Emerging } \\
\text { Presence }\end{array}$ & $\begin{array}{l}\text { Stage- 2 } \\
\text { Enhanced } \\
\text { Presence }\end{array}$ & $\begin{array}{l}\text { Stage- 3 } \\
\text { Interacti } \\
\text { ve }\end{array}$ & $\begin{array}{l}\text { Stage- 4 } \\
\text { Transacti } \\
\text { onal } \\
\text { Presence }\end{array}$ & $\begin{array}{l}\text { Stage- 5 } \\
\text { Participat } \\
\text { ive } \\
\text { Presence }\end{array}$ \\
\hline
\end{tabular}




\begin{tabular}{|l|l|l|c|c|c|}
\hline & & & $\begin{array}{l}\text { Presenc } \\
\mathrm{e}\end{array}$ & & \\
\hline $\begin{array}{l}\text { Dhaka } \\
\begin{array}{l}\text { North City } \\
\text { corporation }\end{array}\end{array}$ & $87.5 \%$ & $80 \%$ & $50 \%$ & $66.67 \%$ & $0 \%$ \\
\hline $\begin{array}{l}\text { Dhaka } \\
\text { South } \\
\text { City } \\
\text { corporation }\end{array}$ & $87.5 \%$ & $80 \%$ & $50 \%$ & $33.33 \%$ & $0 \%$ \\
\hline $\begin{array}{l}\text { Gazipur } \\
\text { City } \\
\text { corporation }\end{array}$ & $87.5 \%$ & $60 \%$ & $50 \%$ & $33.33 \%$ & $0 \%$ \\
\hline $\begin{array}{l}\text { Narayanganj } \\
\text { City } \\
\text { corporation }\end{array}$ & $87.5 \%$ & $50 \%$ & $50 \%$ & $33.33 \%$ & $0 \%$ \\
\hline $\begin{array}{l}\text { Chattogram } \\
\text { City } \\
\text { corporation }\end{array}$ & $75 \%$ & $70 \%$ & $25 \%$ & $0 \%$ & $0 \%$ \\
\hline $\begin{array}{l}\text { Cumilla } \\
\text { City } \\
\text { corporation }\end{array}$ & $75 \%$ & $50 \%$ & $0 \%$ & $0 \%$ & $0 \%$ \\
\hline $\begin{array}{l}\text { Barisal } \\
\text { City } \\
\text { corporation }\end{array}$ & --- & --- & --- & --- & -- \\
\hline $\begin{array}{l}\text { Khulna } \\
\text { City } \\
\text { corporation }\end{array}$ & $62.5 \%$ & $60 \%$ & $50 \%$ & $0 \%$ & $0 \%$ \\
\hline $\begin{array}{l}\text { Mymensingh } \\
\text { City } \\
\text { corporation }\end{array}$ & $87.5 \%$ & $60 \%$ & $25 \%$ & $66.67 \%$ & $0 \%$ \\
\hline $\begin{array}{l}\text { Rajshahi } \\
\text { City } \\
\text { corporation }\end{array}$ & $62.5 \%$ & $60 \%$ & $50 \%$ & $33.33 \%$ & $0 \%$ \\
\hline $\begin{array}{l}\text { Rangpur } \\
\text { City } \\
\text { corporation }\end{array}$ & $87.5 \%$ & $80 \%$ & $50 \%$ & $66.67 \%$ & $0 \%$ \\
\hline $\begin{array}{l}\text { Sylhet } \\
\text { City } \\
\text { corporation }\end{array}$ & $62.5 \%$ & $70 \%$ & & & \\
\hline
\end{tabular}

\section{CONCLUSION AND POLICY OUTCOME}

Assessment at the local government level gives more granularity in assessing the conditions and obstacles of e-governance. UN data shows Bangladesh's overall e-governance has improved from 2010 to 2020 over the years [15]. This paper is an endeavour to understand the state of e-governance at the local government level in Bangladesh.

We have researched 12 city corporations of Bangladesh using a model based on the UN's 5 stage model [10][11] and Kriyar's model [2]. Overall assessment shows that the city corporations have variation in their web presence. Among the 12 city corporations in Bangladesh, we do not find any official website of Barisal City Corporation. The performance of Khulna, Cumilla, and Rajshahi city corporations is very poor than other city corporations. The Dhaka North, Dhaka South are better in giving information. The analysis shows that most city corporations meet emerging and enhanced presence but none ensures participative presence. Most don't have any transactional presence. The assessment confirms the disparity among the local governments that is not understandable via national-level assessment. The findings of the results can be valuable for the policymakers to design more effective e-government system at the local level in the developing world.

\section{ACKNOWLEDGEMENT}

This paper is a result of the project "SmartEGOV: Harnessing EGOV for Smart Governance (Foundations, methods, Tools) / NORTE-01-0145-FEDER-000037", supported by Norte Portugal Regional Operational Programme (NORTE 2020), under the PORTUGAL 2020 Partnership Agreement, through the European Regional Development Fund (EFDR).

\section{REFERENCES}

[1] Kay Singh, June 17, 2013. "Web Design: 11 Characteristics of a User-Friendly Website". SocialMediaToday.

[2] El Kriyar, Dr. Yani Nurhadryani, S.Si, M.T, r. Julio Adisantoso, M.Kom, November, 2011. "Assessment of E-government in Cambodia and Indonesia by Web Measure Index and Web Usability”, DOI: 10.13140/RG.2.2.25235.94240

[3] Zhiyuan Fang, 2002. "E-Government in Digital Era: Concept, Practice, and Development", International Journal of The Computer, The Internet and Management, Vol. 10, No.2, 2002, p 1-22.

[4] Abdulmula AL Bashir. Lusta, Yasar Aktas, 2017. "The Five Models for EGovernment”. Imperial Journal of Interdisciplinary Research (IJIR), Vol-3, Issue-2.

[5] Mithun Barua, October, 2012. "Analyzing the Growth of E-governess with Maturity Model Perspective: A Case of Government Treasures in India”. International Journal of Scientific \& Engineering Research, Volume 3, Issue 10 ,

[6] Valentina (Dardha) Ndou, 2004. "E-government for Developing Countries: Opportunities and Challenges", The Electronic Journal on Information Systems in Developing Countries, EJISDC (2004) 18, 1, 1-24.

[7] About Bangladesh. UNDP. https://www.bd.undp.org/content/bangladesh/en/home/countryinfo.html

[8] Using E-Governess Data to Improve Public Service Delivery: Evidence From Land Record Changes in Bangladesh. Author: Martin Matson. https://www.theigc.org/blog/using-e-governance-data-to-improve-publicservice-delivery-evidence-from-land-record-changes-inbangladesh/?fbclid=IwAR0NeJksg4FXbotyZ0NUP0aR-R-MLCq7M LHNYkShpBv4duPqdTBnQkpVA

[9] UN E-Govt. Surveys. https://publicadministration.un.org/en/research/un-egovernment-surveys

[10] Ronaghan, S.A., Benchmarking E-Government: A Global Perspective. New York: United Nations Division for Public Economics and Public Administration and American Society for Public Administration. 2001.

[11] Szeremeta, J. Benchmarking e-government: a global perspective. in INTERNATIONAL CONGRESS ON GOVERNMENT ON LINE. 2002.

[12] https://publicadministration.un.org/egovkb/Data-Center

[13] Mohammed Alshehri and Steve Drew, "E-GOVERNMENT FUNDAMENTALS". IADIS International Conference ICT, Society and Human Beings, 2010.

[14] M. Alshehri, S. Drew, "Implementation of e-Government: Advantages and Challenges". IASK E-ALT2010 CONFERENCE PROCEEDINGS, page-79-86, 2010.

[15] United Nation Development Program, Human Development reports. http://hdr.undp.org/en/countries/profiles/BGD

[16] Bangladesh Moves up in UNDP Human Development Report, 2019. https://www.bd.undp.org/content/bangladesh/en/home/presscenter/pressrele ases/2019/12/11/HDR_2019_Launching.html

[17] https://www.sehd.org/news/reports/66-bangladeshpopulation\#: :text $=$ miles $\% 2 \mathrm{C} \% 20$ the $\% 20$ size $\% 20$ of $\% 20$ Iowa,square $\% 20$ mile $\% 20$ ( $1114 \% 20$ per\%20sq.

[18] https://drive.google.com/drive/folders/1Fdo10b9jVHZAWABaRoxnncUtLcK3 yujb

[19] https://drive.google.com/drive/folders/1BoxdMzsLWXvIbcv XwHkKHp 4jnr $\underline{\mathrm{XJpu}}$ 